\title{
Genetic substructuring as a result of barriers to gene flow in urban Rana temporaria (common frog) populations: implications for biodiversity conservation
}

\author{
SUSAN P. HITCHINGS \& TREVOR J. C. BEEBEE* \\ Department of Biochemistry, University of Sussex, Falmer, Brighton BN1 9OG, U.K.
}

\begin{abstract}
The ability to maintain small populations in quasi-natural settings is an issue of considerable importance in biodiversity conservation. The genetic structure of urban common frog (Rana temporaria) populations was determined by allozyme electrophoresis and used to evaluate the effects of restricted intersite migration. Despite the lack of any absolute barrier to movement between ponds, substantial genetic differentiation was found between sites separated by an average of only $2.3 \mathrm{~km}$. Genetic distances between these town ponds correlated positively with geographical distances and were almost twice as great as those found between rural sites separated by an average of $41 \mathrm{~km}$. Measures of genetic diversity and fitness were always lowest in the town, where the degree of subpopulation differentiation $\left(F_{\mathrm{ST}}=0.388\right)$ was high. Population decline was not evident in the town, but molecular and fitness data indicated the presence of genetic drift and inbreeding depression. The long-term survival of artificially restricted populations, particularly of relatively sedentary species, may require molecular monitoring, if genetic diversity is not to be lost by chance when facets of the species niche prove to be poorly understood.
\end{abstract}

Keywords: allozymes, biodiversity, conservation genetics, fitness, genetic drift, Rana temporaria.

\section{Introduction}

Continuing anthropogenic disruption of natural population structure has become a major issue among conservationists (Diamond, 1989; Tilman et al., 1994; Kruess \& Tscharntke, 1994). Fragmented populations, especially those of small size, are likely to encounter genetic drift as the major mechanism of genetic change, and this is essentially a random process of loss equivalent to sampling error (see, for example, Falconer, 1989). Such effects have been demonstrated in the natural mosaic habitat of the Ozark Mountains of the United States, where genetic isolation in local populations of a variety of ectothermic animals, with concomitant reduction in subpopulation polymorphism, resulted from historical, geographical and climatic influences (Templeton et al., 1990). Local habitat fragmentation can also affect populations adversely if connectivity is disrupted, as was shown in the Glanville fritillary

\footnotetext{
${ }^{*}$ Correspondence. E-mail: t.j.c.beebee@sussex.ac.uk
}

(Melitaea cinxia), in which the probability of extinction was greatest in small, isolated habitat patches where immigration rates were comparatively low (Hanski et al., 1995). Such findings have resulted in a variety of initiatives to reduce the present and predicted attrition of species numbers. In addition to the creation of nature reserves, these include: plans for wildlife corridors to facilitate colonization and link partitioned ranges (Lindenmayer \& Nix, 1992; Mann \& Plummer, 1995); governmental policies for biodiversity conservation (EEC, 1992); legislation for the protection of endangered species and habitats; and inauguration of reintroduction schemes (Martin, 1994). The majority of these measures, however, involve limitations on population size, immigration and emigration.

To quantify the effects of barriers to gene flow in animal populations on a local scale, we have exploited the quasi-natural environment of an urban town and used the relatively abundant and widespread common frog Rana temporaria (Arnold, 1995) as an example. Concerns over declines in this 
amphibian have been expressed for some time (e.g. Cooke, 1972), although not in the context of urban gardens where provision of new habitat (i.e. garden ponds) was associated with increasing numbers (Beebee, 1979). Rana temporaria is a semiaquatic species, which breeds communally in shallow ponds in early spring (Cooke, 1975a) and exhibits faithfulness to a summer home range (Smith, 1973; Haapanen, 1974) that is usually within $750 \mathrm{~m}$ of the breeding pond (Glandt, 1986). Rana temporaria lays an average of 1300 eggs (Cooke, 1975b) in a single spawn clump. This facilitates study, as subsamples of the progeny of each individual can be taken without confusion of identity or diminution of the population. It was hypothesized that urban Brighton (Sussex, UK) would demonstrate the effects on frog populations of isolating factors consisting of inhospitable intersite terrain created by man and imposed within a comparatively short time period. In 1799 Brighton was an isolated fishing village but today is part of an intensively developed, extensive conurbation with many transecting major roads and railways. It was estimated (Beebee, 1979) that Brighton and its adjoining coastal towns contained $>7000$ R. temporaria breeding ponds. By selecting ponds within the town with no recent history of introductions, it was possible to sample the gene pools of a range of subpopulations. Raising spawn and tadpoles in captivity permitted measures of fitness to be obtained, which could in turn be related to genetic diversity and the developmental history of Brighton. In the surrounding county, large rural populations of the same species existed, which were also sampled and provided a control against which the urban data could be evaluated. The effect on genetic structure of barriers to gene flow is a question likely to be encountered with increasing frequency in communities worldwide.

\section{Methods}

\section{Site selection, sampling and rearing}

Thirteen breeding sites were selected to assess genetic diversity and relative fitness in their $R$. temporaria populations (Table 1). The criteria for selection were that ponds were long-established, traditional breeding sites hosting populations of $R$. temporaria and the toad Bufo bufo (the subject of a separate study) every year. Eight sites were urban, of which six were owned privately and two were public parks where, over many years, humans are known to have removed and deposited spawn. Five rural Sussex sites with large frog populations were also assayed. With the exception of the parks, no site had any known record of introductions within the past 35 years.

The number of breeding anurans was recorded as twice the direct count of spawn clumps made at all urban sites sampled, supplemented by rural population size estimates (this survey and Banks \& Elliott, $1990)$. Female $R$. temporaria produce one spawn clump per year, and the operational sex ratio is generally 1:1 (Cooke, 1975a). Embryos were collected by gently removing a small portion of every

Table 1 Details of sampling sites and populations of Rana temporaria

\begin{tabular}{clrc}
\hline Site & \multicolumn{1}{c}{ Type } & Sample number & Population size \\
\hline Urban & & & \\
1 & Private crematorium & 70 & 140 \\
2 & Private garden & 7 & 40 \\
3 & Private garden & 32 & 14 \\
4 & Public park & 33 & 64 \\
5 & Public park & 5 & 66 \\
6 & Private garden & 80 & 10 \\
7 & Private garden & 11 & 160 \\
8 & Private garden & & 22 \\
Rural & & 100 & $>1000$ \\
A & Wooded heathland & 20 & $100-1000$ \\
B & River valley marsh & 84 & $>1000$ \\
C & Coastal marsh & 100 & $2000-4000$ \\
D & Old parkland & 60 & $>1000$ \\
E & Lake in agricultural setting & & \\
\hline
\end{tabular}

Sample number is the number of spawn clumps from which samples were taken. Population size is twice the spawn clump count. 
accessible spawn clump at each site, up to a maximum of 100 such samples. In all but one urban site (2, where $13 / 20$ spawn clumps sank), every spawn clump at every site was sampled. These were stored temporarily in water from the breeding site and returned immediately to the laboratory, where a total of 100 embryos were carefully removed, by gentle separation of adjacent capsules, from the maximum possible number of these spawn subsamples. Thus, each final sample represented the fullest possible range of genotypes at the breeding location. Spawn was examined briefly under a lower power light microscope at 7-40 $\times$ magnification to confirm that it was undamaged, and the embryos transferred to containers with approximately $8 \mathrm{~L}$ of dechlorinated tap water for culture under uniform conditions.

After resorption of gills, free-swimming larvae were maintained at densities of $<7 \mathrm{~L}^{-1}$ and fed rabbit pellets and blanched lettuce ad libitum. Developmental abnormalities visible to the naked eye and survival were recorded during growth. At about Gosner stage 37 (Gosner, 1960), 24 individuals were randomly selected from each site sample and stored in liquid nitrogen $\left(-196^{\circ} \mathrm{C}\right)$ for subsequent allozyme analysis. All harvested tadpoles and, at the termination of the experiment, all cohort survivors were examined briefly $(7-40 \times$ magnification) to discern structural defects.

Survival curves were constructed from counts made during the growth period, which enabled interpopulation statistical comparisons to be made. The log-rank statistic, LR (Hutchings et al., 1991), which gives an approximation of the conditional log-rank test (Peto \& Pike, 1973), was used in comparisons of survival. Survivorship $(s)$ is calculated as the number alive in a cohort at the beginning of an interval (i), where $S$ is total $s$ at the same time point. LR is then calculated between populations by:

$$
\mathrm{LR}=\frac{\left(d_{n}-E_{n}\right)^{2}}{E_{n}}+\frac{\left(d_{n}-E_{n}\right)^{2}}{E_{n}}+\ldots \text { for all populations, }
$$

where $d_{n}$ is the sum of the interval deaths in population $n$, and $E_{n}$ is the sum of the expected deaths in population $n$. Expected deaths are calculated from the product of $\left(s_{i} / S_{i}\right)$ and $D$, the total of deaths occurring among populations in any $i$. LR was calculated similarly within each time period, using $d_{i n}$, the number of deaths occurring between two census dates and $e_{i n}$, the expected deaths in that interval. The log-rank statistic follows a chi-squared distribution and degrees of freedom are $n-1$, where $n$ is the number of populations. One rural site (E) exhibited atypically high mortality and developmental abnormality of a type associated with nongenetic factors (possibly caused by parasite infection or pesticide pollution) and was therefore excluded from the analysis of survival.

\section{Allozyme analysis}

Protein extracts were homogenates of entire individual larvae, thawed sufficiently to permit crushing and then liquidized on ice in $150 \mu \mathrm{L}$ or $200 \mu \mathrm{L}$ (depending on tadpole size) of ice-cold $50 \mathrm{~mm}$ Tris$\mathrm{HCl}(\mathrm{pH} 8)$ extraction buffer. Homogenates were frozen at $-20^{\circ} \mathrm{C}$ for $15 \mathrm{~min}$ to ensure lysis of subcellular organelles, spun for $15 \mathrm{~min}$ at $8000 \mathrm{~g}$ in a chilled MicroCentaur microcentrifuge to thaw and pellet debris, and supernatants either used immediately or re-stored in liquid nitrogen. An extensive series of trials using standard methodologies (as described, for example, in Richardson et al., 1986) identified 16 enzymes from 19 loci which produced reliable banding patterns on gels during repeated assays. These loci could be resolved using three buffer systems adapted from May (1992). Buffer 1, amine-citrate (morpholine): electrode $40 \mathrm{~mm}$ citric acid, $N$-(3-aminopropyl morpholine) to $\mathrm{pH} 7.1$, gel $1: 9$ dilution of electrode buffer; buffer 2 , discontinuous borate: electrode $320 \mathrm{~mm} \mathrm{H}_{3} \mathrm{BO}_{3}, 60 \mathrm{~mm} \mathrm{LiOH}$ ( $\mathrm{pH} 8.1$ ), gel $50 \mathrm{~mm}$ Tris, $5 \mathrm{~mm}$ citric acid, $10 \mathrm{~mL} \mathrm{~L}^{-1}$ electrode buffer ( $\mathrm{pH} 8.5$ ); buffer 3, Tris citrate: electrode $240 \mathrm{~mm}$ Tris, $94 \mathrm{~mm}$ citric acid, $50 \mathrm{~mm} \mathrm{NaOH}$ ( $\mathrm{pH} 7.2$ ), gel $8 \mathrm{~mm}$ Tris, $3 \mathrm{~mm}$ citric acid, $3 \mathrm{~mm} \mathrm{NaOH}$ (pH 7.7). All gels were 10.5-11.0 per cent (depending upon batch) potato starch (Sigma, UK) and included individuals from different populations as indicators of relative migration. Staining protocols were derived mainly from May (1992), except that buffers were either $100 \mathrm{~mm}$ sodium phosphate $(\mathrm{pH} 7)$ or $50 \mathrm{~mm}$ Tris $(\mathrm{pH} 7$ and $\mathrm{pH} 8$ ) with $100 \mathrm{~mm} \mathrm{KCl}$.

The loci used, abbreviations and buffer system(s) were: aspartate aminotransferase cytosolic, Aat-C, 2 and mitochondrial, Aat $-M, 1$; aconitase, Acon, 3; adenosine deaminase, $A d a, 2$; alcohol dehydrogenase, $A d h, 2,3$ or 1 ; creatine kinase, $C k, 3$; nonspecific esterase, Est, 2 loci, 2; fumarate hydratase, Fum, 2; glutathione reductase, Gr, 3 or 1; isocitrate dehydrogenase, $I d h$, 3; lactate dehydrogenase, $L d h$, 2 loci, 3; mannose-P-isomerase, $M p i, 3$ or 1; nucleoside phosphorylase, $N p, 2$; peptidase A, Pep-A (substrate glycyl-leucine), 2; peptidase B, Pep- $B$ (substrate leucyl-glycyl-glycine), 2; phosphogluconate dehydrogenase, $P g d, 2$; phosphoglucomutase, Pgm, 2. 


\section{Genetic analyses}

Genotype data from biochemical studies were analysed using the computer programs BIOSYS-1 release 1.7 (Swofford \& Selander, 1981), FSTAT version 1.2 (Goudet, 1995), GENEPOP version 1.2 (Raymond \& Rousset, 1995) and PHYLIP (Felsenstein, 1993). Standard statistical analyses were performed using MINITAB release 8. Conformance of loci to the Hardy-Weinberg equilibrium was assessed by chi-squared tests using Yates's correction for degrees of freedom (d.f.) $=1$, and, where d.f. $>1$ and the low values typical of genotype frequencies occurred, a method analogous to the Fisher exact test was employed (Swofford \& Selander, 1981, BIOSYS-1). Population subdivision was assessed by $F$-statistics and $N m$, equivalent to the number of migrants per generation (Wright, 1987). Loci were used in further analysis only when polymorphism was such that a significant difference in allele frequencies existed among populations. Genetic distances were calculated through PHYLIP using Cavalli-Sforza \& Edwards (1967) chord distance with a divisor equal to the degrees of freedom (the number of alleles minus 1). This genetic distance assumes that gene frequency change occurs by drift alone without mutation but not that population sizes have remained constant (Felsenstein, 1993), a model appropriate to the short chronological period involved in the development of the urban environment. Nei's standard genetic distance (Nei, 1987) was also calculated to permit comparison with other studies. The PHYLIP CONTML restricted maximum likelihood method, which is based on the models of Cavalli-Sforza \& Edwards (1967) and Felsenstein (1993), was used to construct trees of relatedness between populations. Consensus trees were obtained by bootstrapping 500 times through the PHYLIP CONSENSE program. The significance of the association between genetic and geographical distance was assessed using a Mantel test (GENEPOP), as the interdependence of matrix data values invalidates significance testing of the product-moment correlation $r . r$ is given, however, as a convenient descriptive statistic of the linear plots of these distances.

To facilitate evaluation of urban Brighton genetic data, an examination of the developmental history of the town was made using ordnance survey (OS) maps and local population statistics. Intersite urban distances were calculated by measurement from large-scale OS maps, which allowed precise location of street boundaries, then plotted onto a 1994 edition OS Pathfinder (1307, TQ20-30) $4 \mathrm{~cm}: 1 \mathrm{~km}$ map. 'Major roads' reported were those defined as $>4 \mathrm{~m}$ wide by this OS map edition.

\section{Results}

\section{Genetic analysis}

Although no formal crosses were carried out, the subunit structures of the enzymes assayed are well characterized as also are the numbers of genetic loci controlling their expression (Noltmann, 1972; Webb, 1984). Without exception, the banding patterns observed in this study were identical to predictions from the above investigations and to those previously carried out on anurans in general (Guttman, 1985) and on Rana, including R. temporaria, in particular (Nishioka et al., 1992). The mean number of alleles per locus, the mean observed heterozygosity $(H)$ per locus and the percentage of these loci that were polymorphic (per cent $P_{\mathrm{m}}$ ) in each $R$. temporaria population are given in Table 2 . The polymorphic loci are given as the percentage actually observed and at the 95 per cent criterion (Wright, 1987).

The urban and rural average number of alleles per locus, $H$ and $P_{\mathrm{m}}$, did not differ significantly, although in all instances genetic diversity was greater in rural than in urban populations. The average conformance of loci to the Hardy-Weinberg equilibrium in urban populations was approximately 58 per cent and in rural populations approximately 69 per cent (after Bonferroni correction for multiple tests of hypothesis; Samuels, 1989, p. 505), and the deviations were always deficiencies of heterozygotes. $F$-statistics and $\mathrm{Nm}$ estimates averaged across all loci are given in Table 3 . All three $F$-statistics in all three population groupings were significantly greater than zero $(P=0.001$; Goudet, 1995). The relative level of inbreeding within populations $\left(F_{\mathrm{IS}}\right)$ was slightly lower in rural locations than in urban locations. When the individual was considered relative to the expected heterozygosity of pooled sites $\left(F_{\mathrm{IT}}\right)$, that difference was greater. $F_{\mathrm{IT}}$ reflects both drift and nonrandom mating (Hartl \& Clark, 1989). $F_{\mathrm{ST}}$, the measure of population subdivision, was more than twice as high in urban than in rural sites.

Urban and rural $F_{\mathrm{ST}}$ (median: urban 0.35 , rural 0.11 ) and $N m$ (median: urban 0.48 , rural 2.13) values were significantly different at the 5 per cent level when judged by Mann-Whitney tests.

Geographical and genetic distances between sites are given in Table 4. The Cavalli-Sforza \& Edwards (1967) chord genetic distance correlated positively with distance in $\mathrm{km}$ between urban sites $(r=0.50, P$ 
Table 2 Genetic summary statistics for the Rana temporaria populations

\begin{tabular}{lcccccc}
\hline Site & $\begin{array}{c}\text { Mean alleles } \\
\text { per locus }\end{array}$ & $\pm \mathrm{SE}$ & $\begin{array}{c}\text { Mean } H \\
\text { per locus }\end{array}$ & $\pm \mathrm{SE}$ & $P_{\mathrm{m}}(\%)$ & $95 \% P_{\mathrm{m}}$ \\
\hline 1 & 1.53 & 0.19 & 0.036 & 0.023 & 36.8 & 21.1 \\
2 & 1.84 & 0.26 & 0.077 & 0.031 & 47.4 & 42.1 \\
3 & 1.37 & 0.17 & 0.042 & 0.027 & 26.3 & 26.3 \\
4 & 1.68 & 0.19 & 0.033 & 0.013 & 52.6 & 31.6 \\
5 & 1.74 & 0.23 & 0.056 & 0.028 & 42.1 & 42.1 \\
6 & 1.74 & 0.23 & 0.043 & 0.017 & 47.4 & 36.8 \\
7 & 1.68 & 0.28 & 0.076 & 0.042 & 31.6 & 31.6 \\
8 & 1.74 & 0.24 & 0.075 & 0.032 & 47.4 & 36.8 \\
$\mathrm{~A}$ & 1.63 & 0.22 & 0.050 & 0.028 & 47.4 & 31.6 \\
$\mathrm{~B}$ & 2.11 & 0.36 & 0.106 & 0.041 & 57.9 & 36.8 \\
$\mathrm{C}$ & 1.53 & 0.19 & 0.063 & 0.037 & 36.8 & 26.3 \\
$\mathrm{D}$ & 2.11 & 0.35 & 0.072 & 0.040 & 57.9 & 36.8 \\
E & 1.58 & 0.19 & 0.058 & 0.028 & 36.8 & 36.8 \\
All & 1.71 & & 0.061 & & 44.3 & 33.6 \\
Urban & 1.65 & & 0.055 & & 41.5 & 33.6 \\
Rural & 1.83 & & 0.073 & & 50.0 & 33.7 \\
\hline
\end{tabular}

$H$, heterozygosity; $P_{\mathrm{m}}$, percentage of polymorphic loci, total or at the 95 per cent level (see Methods).

$($ Mantel $)=0.023)$ and, with town parks excluded (where genetic mixing was believed to take place), the relationship was more pronounced $(r=0.71$, $P=0.002)$. In contrast, comparison of rural genetic distance and geographical distance showed no pattern of association $(r=0.032)$ and this changed little when urban populations were averaged and included as a single Brighton $(\mathrm{Br})$ site $(r=0.095)$. The difference between the urban (average = 0.2320 ) and rural (average $=0.1158$ ) genetic distance means was highly significant $(t=5.56$, $P<0.0001$ ). Nei's genetic distance (data not shown) correlated strongly with the Cavalli-Sforza chord measure $(r=0.967, P<0.001)$ and also showed a similar, albeit weaker, correlation with intersite distances in kilometres between urban sites but not rural ones. Nei's genetic distances between urban sites (average $=0.105$ ) were also significantly higher than the intersite rural distances (average $=0.036$; $t=5.78, P<0.0001$ ).

Table 3 Summary $F$-statistics and gene flow estimates for Rana temporaria populations

\begin{tabular}{lcccc}
\hline Site type & $F_{\text {IS }}$ & $F_{\text {IT }}$ & $F_{\text {ST }}$ & $N m$ \\
\hline All & 0.565 & 0.706 & 0.324 & 0.522 \\
Urban & 0.582 & 0.745 & 0.388 & 0.394 \\
Rural & 0.539 & 0.606 & 0.145 & 1.474 \\
\hline
\end{tabular}

The association between genetic and geographical distances within Brighton was investigated further by examination of urban boundary development in the town over time from OS maps. The number of major roads and railways intersecting the intersite transects was also determined, as roads are known to be significant barriers to migrating amphibians (Cooke, 1972; Fahrig et al., 1995). Weighting the distance in kilometres by $1 \times$ the proportion of the transect developed post-1932 improved correlation with the Cavalli-Sforza chord genetic distance slightly, to $r=0.58, P$ (Mantel $)=0.004$ with town parks and $r=0.74, P$ (Mantel) $=0.001$ without them. Road numbers showed a slight positive association with genetic distance, but the data points were very scattered and, as the urban study area is almost entirely developed, they correlated linearly with distance in any case $(r=0.88, P<0.001)$.

Figure 1 shows a map of the developmental history of Brighton and the urban study sites, together with a CONTML tree of the genetic relationships of $R$. temporaria breeding ponds with approximately proportional branch lengths. The CONTML tree was strongly supported by bootstrapping $(500 \times)$, with all clusters except 7-8 occurring in 87 per cent of cases. The greatest area of uncertainty (the node linking sites $7-8,62$ per cent occurrence) resulted from rearrangement of the order of the three terminal sites. The correlation between 
Table 4 Genetic and geographical distances matrix for Rana temporaria populations

(a) Urban

\begin{tabular}{lccccccccc}
\hline Site & 1 & 2 & 3 & 4 & 5 & 6 & 7 & 8 \\
\cline { 1 - 6 } 1 & & & 1.8 & 2.7 & 3.6 & 3.3 & 4.4 & 3.5 & 4.1 \\
2 & 0.1712 & & 0.9 & 1.8 & 2.6 & 2.6 & 2.3 & 2.7 \\
3 & 0.2459 & 0.1291 & & 1.0 & 2.7 & 1.8 & 2.0 & 2.2 \\
4 & 0.1955 & 0.2561 & 0.2820 & & 2.7 & 0.8 & 1.7 & 1.6 \\
5 & 0.2314 & 0.2585 & 0.2541 & 0.0614 & & 2.9 & 1.1 & 1.7 \\
6 & 0.4100 & 0.3705 & 0.4078 & 0.1987 & 0.1637 & & 1.8 & 1.4 \\
7 & 0.3221 & 0.2960 & 0.3213 & 0.1206 & 0.0817 & 0.1344 & & 0.7 \\
8 & 0.3420 & 0.3089 & 0.3544 & 0.1848 & 0.1292 & 0.1886 & 0.0752 & \\
\hline
\end{tabular}

(b) Rural + Brighton (mean of eight urban sites)

\begin{tabular}{lcccccc}
\hline Site & A & B & C & D & E & Br \\
\hline A & & 22 & 37 & 73 & 34 & 29 \\
B & 0.1417 & & 27 & 66 & 24 & 11 \\
C & 0.0422 & 0.1460 & & 93 & 52 & 36 \\
D & 0.1297 & 0.1550 & 0.1113 & & 42 & 57 \\
E & 0.0726 & 0.1563 & 0.0789 & 0.1470 & & 16 \\
Br & 0.1183 & 0.1323 & 0.0939 & 0.0929 & 0.1182 &
\end{tabular}

Cavalli-Sforza (1967) chord genetic distances (lower triangles) and geographical distances in $\mathrm{km}$ (upper triangles).

geographical and genetic (tree) locations of the study sites was striking.

Although no relationship between genetic distance and distance in kilometres was found for the five rural sites, they were also analysed by CONTML. The resultant tree (not shown) maintained its branching structure after bootstrapping but clusters had low percentage reproducibility ( $\leq 57$ per cent).

\section{Fitness assessments}

The survivorship curves for urban and rural $R$. temporaria larvae cultured under controlled conditions are given in Fig. 2.

Survivorship among the 12 sites, as tested by the log-rank statistic (LR), was not uniform, either within the time intervals examined or between cohorts (Table 5).

The highest levels of significance were associated with early development, when the greatest mortality occurred. Clustering deaths during all four census intervals as either urban or rural showed significant overall differences between the two groups (MannWhitney test, $P=0.042$ ) with median urban deaths in any census interval equal to 5 and median rural deaths equal to 2 . The difference between the number of developmental abnormalities observed in urban as opposed to rural tadpoles was also significant $(P=0.042)$ when evaluated by the MannWhitney test (urban median $=8.00$, rural median $=$ 3.50). A statistically significant negative correlation $(r=-0.80, P=0.002)$ existed between survival at day 80 and $\log _{10}$ abnormalities, although these factors may not be truly independent: abnormal tadpoles may have died, contributing to lowered survival. Similarly, malformations, such as tail-tip kinks, in early larvae may have become invisible as development proceeded.

\section{Discussion}

Urban populations of common frogs exhibited higher degrees of genetic substructuring and lower levels of average genetic diversity than their rural counterparts, and also experienced higher levels of mortality and developmental abnormality when larval growth was compared in controlled conditions. It is generally believed that breakdown of developmental homeostasis is an indicator of inbreeding (Mitton \& Grant, 1984) and the phenomenon of developmental abnormality has a long association with lack of genetic variety. The correlation of 
genetic distance with small-scale geographical distance within the town suggests that, despite the lack of absolute barriers to migration, these populations have become differentiated genetically by drift. Genetic distances between urban $R$. temporaria ponds separated by $0.7-4.4 \mathrm{~km}$ were, on average, twice as great as those between the much more widely dispersed rural sites (mean separation $41.3 \mathrm{~km}$ ). Historical and ethological considerations suggest that the causative isolating factor was the increasingly inhospitable terrain of the urban environment, as the association between genetic and geographical distance was enhanced if weighted for recent development. This finding was reflected in the high degree of urban subpopulation differentiation, which resulted in $N m$ values averaging 0.394, considerably less than the value of 1 , below which allele frequency changes mediated by drift are prob- able (see, for example, Slatkin, 1985). In comparison, mean rural $\mathrm{Nm}$ was 1.474 . The distinctive relationship between the urban genetic tree and the geographical locations emphasized the strength of the isolating factors. The juxtaposition on the CONTML tree of the admixed populations of urban parks, which were distant geographically, provided supporting evidence for the validity of the tree branching structure.

This investigation indicates that the impact of habitat change on the genetic diversity of a species can be rapid and superficially undetectable at the phenotypical level. Amphibians appear to be well adapted to the urban habitat, are locally abundant and will colonize nearby ponds, but there appears to be insufficient progressive migration to maintain panmixia over even relatively short distances. What might be considered a metapopulation (Hanski,
Fig. 1 Geographical and genetic relatedness of populations of Rana temporaria. Top: urban Brighton with site numbers and boundaries of development at the given dates. Major roads are shown by solid lines. TQ28-34 gridline $=6 \mathrm{~km}$. Bottom: CONTML tree of genetic relatedness of populations in the urban sampling sites from allozyme allele frequencies.
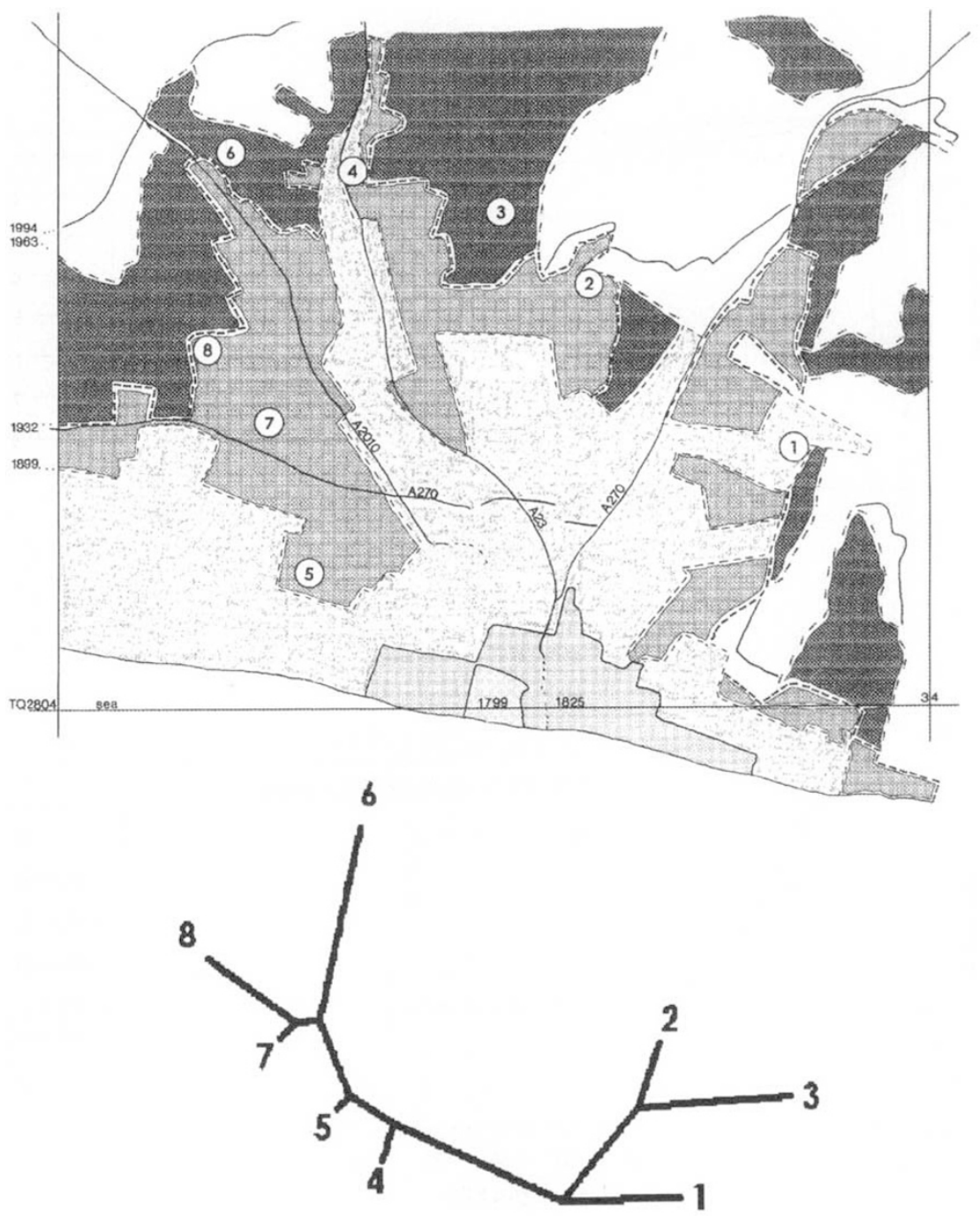
1991; Hanski \& Gilpin, 1991) because of the very large number of urban ponds with opportunity for random extinction and recolonization, appears instead to be a collection of small, relatively independent populations becoming progressively more isolated in genetic space as barrier strength increases. It therefore seems that the urban environment has prevented frog populations from exchanging sufficient individuals to avoid genetic drift, that this is a continuing process despite the existence of many suitable ponds in the area and that this random loss of alleles has resulted in fitness reduction by inbreeding depression. It is of some interest in this context that disease epidemics in urban frog populations, perhaps related to reduced fitness, have received considerable attention recently (e.g. Cunningham et al., 1993). On the other hand, translocations of frogs from garden environments to start new populations have proved successful (e.g. Cooke
\& Oldham, 1995), perhaps because spawn from multiple sites was pooled for the purpose.

Table 6 shows some comparative genetic data for amphibian taxa. Genetic variation of Brighton and Sussex $R$. temporaria was in a range similar to that observed among 12 Rana species (Nishioka et al., 1992). In Germany, 20 rural populations of $R$. temporaria (Reh \& Seitz, 1990) had higher overall genetic diversity and exhibited significant associations of genetic distance with intersite motorways and railways. $H$ was, however, comparatively low in Brighton $R$. temporaria and, in urban populations, $H$ and $F_{\mathrm{ST}}$ were similar to those reported in salamanders. Mobility in the Amphibia is inherently restricted by a requirement for a moist environment, and high values of $F_{\mathrm{ST}}$ have been reported regularly, for example in a group of 22 salamanders (Larson $e t$ al., 1984) with mean $F_{\mathrm{ST}}=0.53$ and consequently low estimates of migration, $\mathrm{Nm}$. It was considered
URBAN POPULATIONS

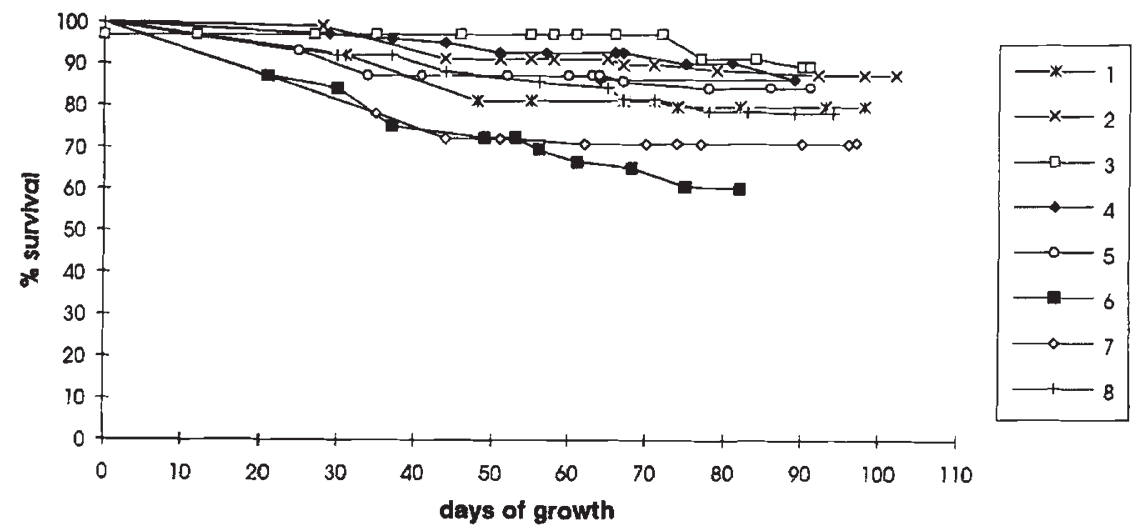

RURAL POPULATIONS

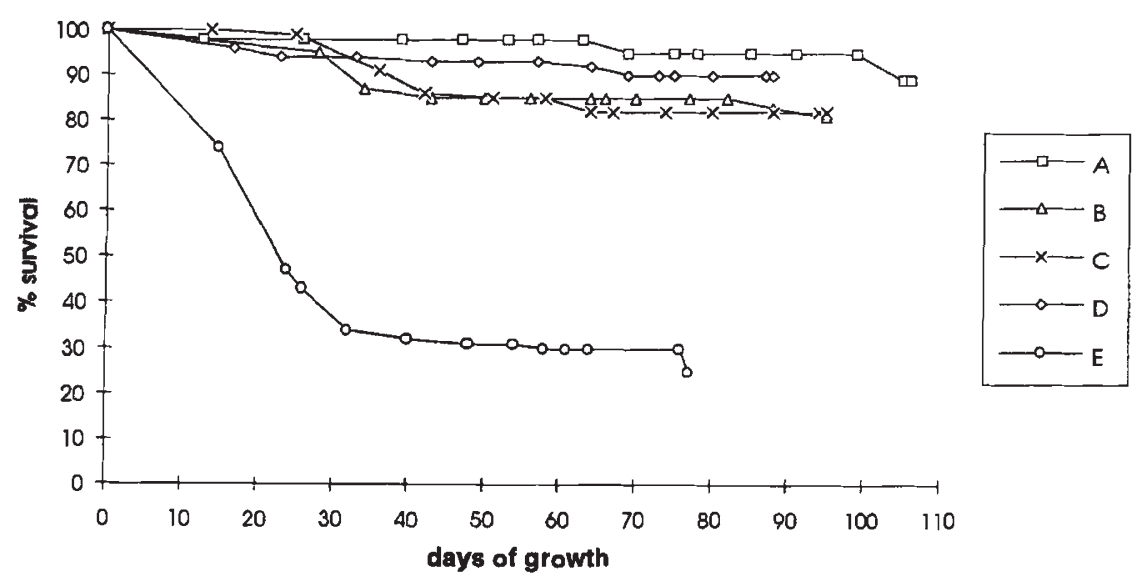

Fig. 2 Survival during growth in controlled conditions of Rana temporaria larvae. The keys refer to individual sites. 
by these authors that the relatively high levels of $F_{\text {ST }}$ could be explained by a history of glacial isolation and recolonization, coupled with the inherently low mobility of small amphibians.

The imposed isolation of common frogs in Brighton is typical of many other species in the UK. In present-day England, $>40$ per cent of the land area is converted to intensive human use, with about 10 per cent urban and the remainder arable, and a

Table 5 Survivorship differences between Rana temporaria larvae from different populations

\begin{tabular}{lcc}
\hline $\begin{array}{l}\text { Census period } \\
\text { (days) }\end{array}$ & $\begin{array}{c}\text { Log-rank } \\
\text { statistic }\end{array}$ & Significance $(P)$ \\
& d.f. $=11$
\end{tabular}

(a) Between populations at a single census time

$\begin{array}{lll}0-24 & 43.486 & 0.001 \\ 25-39 & 41.293 & 0.001 \\ 40-59 & 28.701 & 0.01 \\ 60-79 & 23.156 & 0.05\end{array}$

(b) Between total deaths in cohorts

$0-79$

70.204

0.001

Data are from 12 urban and rural populations.

Probabilities are of departures from expected values. further third exists as managed grassland (Barr et al., 1993). Such intensive land management imposes discontinuity on the remaining habitat (Thornton \& Kite, 1990) as segments of unsuitable terrain (urban, industrial and agricultural) are interspersed among the undeveloped, seminatural areas, with resultant fragmentation of population connectivity.

The majority of natural population losses result from extensive habitat change caused by the recent rapid increase in the human population of the world, from approximately $0.7 \times 10^{9}$ in 1700 to approximately $5.0 \times 10^{9}$ at present (Demeny, 1990; Kates et al., 1990). Widespread concern exists over the extinction of species (Ehrlich \& Wilson, 1991), with widely varying estimates of rates and numbers of losses, including the suggestion (May et al., 1995) that the average species lifetime may have been reduced from $10^{6}$ years to 300 years. Internationally, habitat destruction has been highlighted in tropical rainforests, where recent estimates of annual rates of deforestation in the Brazilian Amazon approached $2.0 \times 10^{6}$ ha (Skole et al., 1994).

It is apparent that careful consideration of all facets of a species niche and lifestyle will be necessary if the genetic diversity of populations is to be maintained in natural communities. A wildlife corridor

Table 6 Comparative amphibian genetic diversity statistics

\begin{tabular}{llcccc}
\hline Key & \multicolumn{1}{c}{ Subject } & $\begin{array}{c}\text { Mean alleles } \\
\text { per locus }\end{array}$ & $\begin{array}{c}\text { Mean } H \\
\text { per locus }\end{array}$ & $\begin{array}{c}\text { Mean } \\
P_{\mathrm{m}}(\%)\end{array}$ & $F_{\text {ST }}$ \\
\hline 1 & Bufo spp. & 1.4 & 0.115 & $39^{*}$ & - \\
2 & B. japonicus & 1.5 & 0.107 & $36^{*}$ & 0.244 \\
3 & B. bufo & 1.2 & 0.023 & 18 & 0.487 \\
4 & Rana spp. & 1.4 & 0.101 & $33^{*}$ & 0.289 \\
5 & R. temporaria & 2.1 & 0.170 & 66 & - \\
6 & R. temporaria & 1.7 & 0.061 & 44 & 0.324 \\
7 & Salamandra salamandra & 1.5 & 0.078 & 36 & 0.403 \\
8 & Triturus italicus & 1.3 & $0-0.09$ & 19 & 0.448 \\
\hline
\end{tabular}

1. Bufo spp. (Nishioka et al., 1990). Twenty-three populations of seven bufonid species, including six subspecies of $B$. japonicus.

2. Bufo japonicus (Kawamura et al., 1990). Five subspecies in 40 Japanese populations.

3. Bufo bufo (Hitchings \& Beebee, in preparation). Data from the urban and rural locations of this report.

4. Rana spp. (Nishioka et al., 1992). Thirty populations of 12 ranid species.

5. Rana temporaria (Reh \& Seitz, 1990). Twenty rural German populations of

10-360 individuals.

6. This study, overall averages.

7. Salamandra salamandra (Alcobendas et al., 1996). Two conspecific lineages and 13 populations.

8. Italian newt Triturus italicus (Ragghianti \& Wake, 1986). Eleven populations in southern Italy. 
will remain a barrier if it does not provide habitat for species that cannot simply walk straight through. Using amphibians as an example, ponds and suitable non-breeding season territory need to be within an uninterrupted territorial range if they are to function as staging posts in a sequential process of colonization. It will be most important to monitor genetic diversity, at least in a representative group of relatively sedentary taxa, to assess changes that might commence because an essential aspect of the species requirements has been overlooked or underestimated.

\section{Acknowledgements}

We are grateful to the Biotechnology and Biological Sciences Research Council and to English Nature, especially Tony Gent, for assistance with funding; to the authors of PHYLIP, GENEPOP and FSTAT for their free provision of analytical software and to the many site owners who allowed free access to their ponds during the course of this study.

\section{References}

ALCOBENDAS, M., DOPAZO, H. AND ALBERCH, P. 1996. Geographic variation in allozymes of populations of Salamandra salamandra (Amphibja: Urodela) exhibiting distinct reproductive modes. J. Evol. Biol., 9, 83-102.

ARNOLD, H. R. 1995. Atlas of Amphibians and Reptiles in Britain. ITE research publication 10. HMSO, London.

BANKS, B. AND Ellıotr, M. 1990. Amphibians in Sussex a Site Inventory. Sussex Amphibian and Reptile Group. Unpublished report.

BARR, C. J., BUNCE, R. G. H., CLARKE, R. T., FULLER, R. M., FURSE, M. T., GIllesPie, M. K. ET AL. 1993. Countryside Survey 1990 Main Report. Department of the Environment, London.

BEEBEE, T. J. C. 1979. Habitats of the British amphibians (2): suburban parks and gardens. Biol. Conserv., 15, 241-257.

CAVAlli-SForZA, L. L. AND EDWARds, A. W. F. 1967. Phylogenetic analysis: models and estimation procedures. Evolution, 21, 550-570.

COOKE, A. S. 1972. Indications of recent changes in the British Isles of the frog (Rana temporaria) and the toad (Bufo bufo). J. Zool. Lond., 167, 161-178.

COOKE, A. S. 1975a. Spawn site selection and colony size of the frog (Rana temporaria) and the toad (Bufo bufo). J. Zool. Lond., 175, 29-38.

COOKE, A. S. 1975b. Spawn clumps of the common frog Rana temporaria: number of ova and hatchability. $\mathrm{Br} . J$. Herpetol, 5, 505-509.

COOKE, A. S. AND OLDHAM, R. S. 1995. Establishment of populations of the common frog, Rana temporaria, and common toad, Bufo bufo, in a newly created reserve following translocation. Herpetol. J., 5, 173-180.

CUNNINGHAM, A. A., LANGTON, T, E. S., BENNETT, P, M., DRURY, S. E. N., GOUGH, R. E. AND KIRKWOOD, J. K. 1993. Unusual mortality associated with poxvirus-like particles in frogs (Rana temporaria). Vet. Record, 133, 141-142.

Demeny, P. 1990. Population. In: Turner, B. L., Clark, W. C., Kates, R. W., Richards, J. F., Mathews, J. T, and Meyer, W. B. (eds) The Earth as Transformed by Human Action, pp. 41-54. Cambridge University Press, Cambridge.

DIAMOND, J. M. 1989. The present, past and future of human-caused extinctions. Phil. Trans. R. Soc. B, 325, $469-477$.

EEC 1992. Council Directive 92/43/EEC of 21 May 1992 on the Conservation of Natural Habitats and of Wild Fauna and Flora. European Commission, Brussels.

EHRLICH, P. R. AND WILSON, E. O, 1991. Biodiversity studies: science and policy. Science, 253, 758-762.

FAHRIG, L., PEDLAR, J. H., POPE, S. E., TAYLOR, P. D. AND WEGNER, J. F. 1995. Effect of road traffic on amphibian density. Biol. Conserv., 73, 177-182.

FALCONER, D. S. 1989. Introduction to Quantitative Genetics, 3rd edn. Longman, Essex.

FELSEnSteIn, J. 1993. PHYLIP (Phylogeny Inference Package) version $3.5 c$ distributed by the author. Department of Genetics, University of Washington, Seattle.

GLANDT, D. 1986. Die saisonalen wanderungen der mitteleuropäischer amphibien. Bonn. zool. Beitr., 37, 211-228.

GOSNER, K. L. 1960. A simplified table for staging anuran embryos and larvae with notes on identification. Herpetologica, 16, 183-190.

GOUDET, J. 1995. FSTAT V-1.2; a computer program to calculate $F$-statistics. J. Hered., 86, 485-486.

GUTTMAN, S. I.. 1985. Biochemical studies of anuran evolution. Copeia, 2, 292-309.

HAAPANEN, A. 1974. Site tenacity of the common frog (Rana temporaria L.) and the moor frog $(R$. arvalis Nilss.). Ann. Zoo. Fenn., 7, 61-66.

HANSKI, I. 1991. Single-species metapopulation dynamics: concepts, models and observations. In: Gilpin, M. and Hanski, I. (eds) Metapopulation Dynamics: Empirical and Theoretical Investigations, pp. 17-38. The Linnean Society of London/Academic Press, London.

HANSKI, I. AND GILPIN, M. 1991. Metapopulation dynamics: brief history and conceptual domain. In: Gilpin, M. and Hanski, I. (eds) Metapopulation Dynamics: Empirical and Theoretical Investigations, pp. 3-16. The Linnean Society of London/Academic Press, London.

HANKSI, I., PÖYRY, J., PAKKALA, T. AND KUUSSAARI, M. 1995. Multiple equilibria in metapopulation dynamics. Nature, 377, 618-621.

Hartl, D. L. And Clark, A. G. 1989. Principles of Population Genetics. Sinauer, Sunderland, MA.

HUTCHINGS, M. J., BOOTH, K. D. AND WAITE, S. 1991. Comparison of survivorship by the logrank test: criticisms and alternatives. Ecology, 72, 2290-2293. 
KATES, R. W., TURNER, B. L. AND CLARK, W. C. 1990. The great transformation. In: Turner, B. L., Clark, W. C., Kates, R. W., Richards, J. F., Mathews, J. T. and Meyer, W. B. (eds) The Earth as Transformed by Human Action, pp. 1-17. Cambridge University Press, Cambridge.

KAWAMURA, T., NISHIOKA, M., SUMIDA, M. AND RYUZAKI, M. 1990. An electrophoretic study of genetic differentiation in 40 populations of Bufo japonicus distributed in Japan. Sci. Report Lab. Amphib. Biol., Hiroshima Univ., 10, 1-51.

KRUESS, A. AND TSCHARNTKE, T. 1994. Habitat fragmentation, species loss, and biological control. Science, 264, 1581-1584.

LARSON, A., WAKE, D. B. AND YANEV, K. P. 1984. Measuring gene flow among populations having high levels of genetic fragmentation. Genetics, 106, 293-308.

LINDENMAYER, D. B. AND NIX, H. A. 1992. Ecological principles for the design of wildlife corridors. Conserv. Biol., 7, 627-630.

MANN, C. C. AND PLUMMER, M, L. 1995. Are wildlife corridors the right path? Science, 270, 1428-1430.

MARTIN, C. M. 1994. Recovering endangered species and restoring ecosystems: conservation planning for the twenty-first century in the United States. Ibis, 137, s198-s203.

MAY, B. 1992. Starch gel electrophoresis of allozymes. In: Hoelzel, A. R. (ed.) Molecular Genetic Analysis of Populations, pp. 1-27 and 271-280. IRL Press, Oxford.

MAY, R. M., LAWTON, J. H. AND STORK, N. E. 1995. Assessing extinction rates. In: Lawton, J. H. and May, R. M. (eds) Extinction Rates, pp. 1-24. Oxford University Press, Oxford.

MITTON, J. B. AND GRANT, M. C. 1984. Associations among protein heterozygosity, growth rate and developmental homeostasis. Ann. Rev. Ecol. Syst., 15, 479-499.

NEI, M. 1987. Molecular Evolutionary Genetics. Columbia University Press, New York.

NISHIOKA, M, SUMIDA, M., UEDA, H. AND WU, z. 1990. Genetic relationships among 13 Bufo species and subspecies by the method of electrophoretic analyses. Sci. Report Lab. Amphib. Biol., Hiroshima Univ., 10, 53-91.

NISHIOKA, M., SUMIDA, M., BORKIN, L. J. AND WU, Z. 1992. Genetic differentiation of 30 populations of 12 brown frog species distributed in the Palearctic region elucidated by the electrophoretic method. Sci. Report Lab. Amphib. Biol., Hiroshima Univ., 11, 109-160.
NOLTMANN, E. A. 1972. Aldose-ketose isomerases, In: Boyer, P. D. (ed.) Enzymes, 3rd edn, vol. 6, pp. 271-254. Academic Press, New York.

PETO, R. AND PIKE, M. C. 1973. Conservatism of the approximation $\Sigma(\mathrm{O}-\mathrm{E})^{2} / \mathrm{E}$ in the logrank test for survival data or tumor incidence data. Biometrics, 29, 579-584.

RAGGHIANTI, M. AND WAKE, D. B. 1986. Genetic variation and its evolutionary implications in the Italian newt, Triturus italicus. Herpetologica, 42, 206-214.

RAYMOND, M. AND ROUSSET, F. 1995. GENEPOP (version 1.2): a population genetics software for exact tests and ecumenicism. J. Hered., 86, 248-249.

REH, W. AND SEITZ, A. 1990. The influence of land use on the genetic structure of populations of the common frog Rana temporaria. Biol. Conserv. 54, 239-249.

RICHARDSON, B. J., BAVERSTOCK, P. R. AND ADAMS, M. 1986. Allozyme Electrophoresis. A Handbook for Animal Systematics and Population Studies. Academic Press, San Diego, CA.

SAMUELS, M. 1989. Statistics for the Life Sciences. Dellen, San Francisco.

SKOLE, D. L., CHOMENTOWSKI, W. H., SALAS, W. A. AND NOBRE, A. D. 1994. Physical and human dimensions of deforestation in Amazonia. BioScience, 44, 314-321.

SLATKIN, M. 1985. Rare alleles of indicators of gene flow. Evolution, 39, 53-65.

smith, м. 1973. The British Amphibians and Reptiles. Collins, London.

SWOFFORD, D. L. AND SELANDER, R. B. 1981. BIOSYS-1: a FORTRAN program for the comprehensive analysis of electrophoretic data in population genetics and systematics. J. Hered., 72, 281-283.

TEMPLETON, A. R., SHAW, K., ROUTMAN, E. AND DAVIS, S. K. 1990. The genetic consequences of habitat fragmentation. Ann. Mo. Bot. Gard., 77, 13-27.

THORNTON, D. AND KITE, D. J. 1990. Changes in the Extent of the Thames Estuary Grazing Marshes. Nature Conservancy Council, Peterborough.

TILMAN, D., MAY, R. M., LEHMAN, C. L. AND NOWAK, M. A. 1994. Habitat destruction and the extinction debt. Nature, 371, 65-66.

WEBB, E. C. 1984. Enzyme Nomenclature 1984. International Union of Biochemistry. Academic Press, London.

Wright, s. 1987. Evolution and the Genetics of Populations, vol. 4, Variability Within and Among Natural Populations. University of Chicago Press, Chicago. 